\title{
Bioimpact on weathering steel surfaces: Oxalates formation and the elucidation of their origin
}

\author{
Julene Aramendia a, ${ }^{*}$, Leticia Gomez-Nubla ${ }^{\text {, }}$, Ludovic Bellot-Gurlet ${ }^{\text {b }}$, Kepa Castro ${ }^{\text {, }}$ \\ Gorka Arana a , Juan Manuel Madariaga a \\ a Department of Analytical Chemistry, University of the Basque Country UPV/EHU, P.O. Box 644, E-48080, Bilbao, Spain \\ b Sorbonne Universités, UPMC Université Paris 6, MONARIS “de la Molécule aux Nano-objets: Réactivité, Interactions et Spectroscopies”, UMR 8233, \\ UPMC-CNRS, 75252, Paris Cedex 05, France
}

\section{A R T I C L E I N F O}

\section{Article history:}

Received 16 January 2015

Received in revised form

11 May 2015

Accepted 12 May 2015

Available online $\mathrm{xxx}$

\section{Keywords:}

Weathering steel

Oxalates

Humboldtine

Raman spectroscopy

Thermodynamic

\begin{abstract}
A B S T R A C T
This study was carried out to elucidate the causes of irregularities and discolorations on the surface of parts of a weathering steel sculpture which had been in contact with wood pallets. Non-destructive analysis of the samples by Raman spectroscopy revealed the presence of iron oxalates and calcium oxalates. Thermodynamic modeling suggested that the detected oxalates were produced by the reaction of oxalic acid, a potential metabolite excreted by microorganisms, and elements present in the steel surface such as iron. Carotenoids including $\beta$-carotene and astaxanthin, biomarkers for a large number of prokaryotic and eukaryotic microorganisms, were also detected in samples.
\end{abstract}

(C) 2015 Elsevier Ltd. All rights reserved.

\section{Introduction}

It is well known that weathering steel, in spite of being a high strength alloy, can be affected by the surrounding environment (Arroyabe and Morcillo, 1995; Oesch, 1996; Wang et al., 1997; Kamimura et al., 2006; Chiavari et al., 2012.) The effects of acid gases $\left(\mathrm{CO}_{2}, \mathrm{SO}_{2}\right.$ and $\left.\mathrm{NO}_{\mathrm{x}}\right)$ which produce $\mathrm{H}_{2} \mathrm{CO}_{3}, \mathrm{H}_{2} \mathrm{SO}_{4}$ and $\mathrm{HNO}_{3}$ react with the iron and the other elements present in the steel, as well as with the particles that are deposited on the steel surface, have been extensively investigated (Aramendia et al., 2013). The products of these reactions can generate physical stress due to the volume changes of the different reaction products (Aramendia et al., 2013, 2014a). These compounds have higher solubility constants than their respective oxides and they are easily leached by the precipitation runoff. Severe consequences of this leaching process include the material loss, visual alteration of the surface, environmental problems if heavy metals are leached, etc. In addition, the presence of silicates can retard the normal evolution of the weathering steel protective corrosion layer (Aramendia et al.,

\footnotetext{
* Corresponding author.

E-mail address: julene.aramendia@ehu.es (J. Aramendia).
}

2012). In the case of weathering steel used in Cultural Heritage there is no consensus about the main factors in the acceleration of decay. Some authors blame acid rain and pollution in general, but others state that biological activity is the most important agent in the degradation process (Dornieden et al., 2000). Therefore, biological degradation should be studied thoroughly in order to obtain a more precise description of decaying processes.

The interest in microorganisms has greatly increased due to the problems of degradation they produce (Chertov et al., 2004). For example, biodegradation processes in wood, wall-paintings, buildings and in other carbonaceous matrices have been thoroughly studied (Mandrioili et al., 2003; St. Clair and Seaward, 2004; Sterflinger, 2010; Kozirog et al., 2014). Biofilms lead to discoloration and/or changes in characteristics such as brightness, smoothness, hydrophobicity, etc. In addition, the biofilm can retain water, (Gaylarde et al., 2011) which can produce further damages. Apart from aesthetical and chemical problems, some fungi can insert their hyphae deeply into the substrate. This fact can generate a severe physical stress, (Laiz, 2015) resulting in a reduction of the durability of the material.

The consequences of biological activity in iron or steel are diverse, ranging from pitting, crevice formation, under-deposit corrosion to stress corrosion cracking (Yuan and Pehkonen, 
2007). However, regarding the steel world, the most studied process related to biological activity has been the Microbiologically Influenced Corrosion (MIC) (Javaherdashti et al., 2006; Basheer et al., 2013). MIC in steel and iron alloys is a process promoted, produced or accelerated by the action of microorganisms (Miranda et al., 2006; Rémazeilles et al., 2010). The heterogeneous biofilm and the associated bacteria develop complex biological systems that can cause several chemical changes at the metal/biofilm interface, such as producing gradients in $\mathrm{pH}$, dissolved oxygen, chloride and sulphate (Yuan and Pehkonen, 2007). In fact, one of the most known phenomena is the production of sulfide induced in anoxic environments by sulfate-reducing bacteria (SRB) (Miranda et al., 2006; Rémazeilles et al., 2010).

In contrast to other matrices (Castro et al., 2008; Hernanz et al., 2008; Prinsloo et al., 2008; Perez-Rodriguez et al., 2011; Tournié et al., 2011) such as stone surfaces, frescoes and cave paintings, oxalate biomineralization has not been yet reported on steel. Oxalates are produced by the biochemical activity of some lichens, algae, fungi or bacteria whose metabolic processes excrete oxalic acid $\left(\mathrm{H}_{2} \mathrm{C}_{2} \mathrm{O}_{4}\right)$, which reacts with substrates including stones, pigments or mortars, (Castro et al., 2008; Rosado et al., 2013) and the biomineralization can cause structural and aesthetical problems (Rosado et al., 2013).

In this work, a weathering steel sculpture which was in contact with a wooden pallet during the transportation of the artwork was studied since it presented a very irregular surface and some discoloration areas that affected the visual appearance of the artwork. The Protective Ability Index (PAI), used for assessing the conservation state of weathering steel structures and calculated by the ratio of the active iron phases present in the protective rust layer and the stable ones (Aramendia et al., 2014b), was the expected one for the artwork's exposition time (Aramendia et al., 2014b). Moreover, there was not a high concentration of soluble salts present on the surface. Therefore, it was hypothesized that some factors related to the contact between wood and the steel surface were producing surface deterioration agents in this sculpture perhaps induced by biologic activity such as oxalates.

\section{Material and methods}

The samples were taken from a weathering steel sculpture exhibited outdoors and exposed to the environment of Bilbao city. The artwork is called Plow and it was created in 1992 by the sculptor Richard Serra. It is exhibited in the Guggenheim Museum of Bilbao since 2008. For its transportation to the museum some wooden pallets were used. As it can be observed in Fig. 1, in the place where the pallets were in contact with the steel, some discoloured and irregular stripes appeared. For the study of these areas, some samples were collected from the steel surface. As it can be seen in Fig. 1C, the protective layer of this weathering steel structure was detaching from the surface as little steel chips or flakes. Micro-samples corresponding to the minimum material needed for the analysis (around $1 \mathrm{mg}$ of corroded steel) were collected with a scalpel. Signs of biological activity such as spider nests and little insects were observed at the sampling sites. The visual observation of the samples was performed with an Olympus optical microscope BX51 (Tokyo, Japan) under various magnifications $(5 \times$ to $50 \times)$.

For structural characterization, the samples were analyzed by Raman spectroscopy, a non-destructive and non-invasive technique that allows analysis of the sample directly, without any pretreatment. An additional advantage of this technique is the possibility of storage of the samples for future additional examinations, thus avoiding the necessity of sampling the sculpture again and consuming more material.
For the Raman analysis, a LabRam HR800 (Horiba Jobin Yvon company, Villeneuve d'Ascq, France) spectrometer was employed at the MONARIS lab. This equipment is characterised by a focal length of $800 \mathrm{~mm}$, equipped by a Peltier cooled CCD detector and coupled to an ionised argon Laser from Coherent (I-90C-6). Analyses were performed using the $514.5 \mathrm{~nm}$ line and the Rayleigh filtering was achieved using Ultra Low Frequencies (ULF) BragGrate Notch Filter. Using a 600 lines/mm grating (allowing the recording in one acquisition of the whole spectral range of our interest) the spectral resolution of the equipment was around $3 \mathrm{~cm}^{-1}$ and it was calibrated daily with a silicon chip at $520.5 \mathrm{~cm}^{-1}$. The measurements were performed with the $50 \times$ and $100 \times$ objectives of an Olympus microscope BX41 (Tokyo, Japan) coupled to the spectrometer providing analysis diameters of about $3 \mu \mathrm{m}$ and $1 \mu \mathrm{m}$. The latter objective and the confocality of the system allowed the analysis of the biological compound alone avoiding the iron oxide signals that were quite intense in these samples. In order to avoid thermodecompositions and mineral phase changes, the laser power was modulated (power supply and density filters), always maintaining it below $150 \mu \mathrm{W}$ at the sample using the $100 \times$ objective. This fact was important for example for the iron oxalate since it can be thermally decomposed at moderate temperatures (Diefallah et al., 2002). Acquisitions were performed with LabSpec software (Jobin Yvon-Horiba, Villeneuve d'Ascq, France). The spectra interpretation was performed by comparison with pure standard compounds contained in an in-house database (Castro et al., 2005), in the RRUFF online database (Downs, 2006) and in the literature.

$\mathrm{pH}$ and Redox were measured in $20 \mathrm{ml}$ of dripping water collected from the sculptures during rain. The parameters were measured in-situ using different electrodes: Crison 52-02 (Barcelona, Spain) electrode for $\mathrm{pH}$ measurements and Crison 52-61 (Barcelona, Spain) for the redox potential.

\section{Results and discussion}

Translucent filaments with star-shaped structures at the edges were observed in the part of the sculpture surface that was in contact with the wood (Fig. 2).

Several carotenoids were detected by Raman spectroscopy on the Plow surface (Fig. 3). These compounds are biomarkers for lichen and moss since they occur in the pigmentation of these organisms (Edwards et al., 1997). Moreover, algae and cyanobacteria biosynthesize carotenoids as a mechanism to increase their resistance to extreme environments, like those with high UV radiation and/or acid gases (Maguregui et al., 2012). These carotenoids can be easily detected by Raman spectroscopy using a green laser because these wavelengths fall in the absorption band of these molecules, generating a resonance effect. Consequently, Raman signatures are significantly enhanced and some resonant Raman bands are also present in the spectra. These additional bands permit the identification of the different types of carotenoids (Edwards et al., 1997; Maguregui et al., 2012; Rivera and Pena-Diaz, 2012).

In this work, $\beta$-carotene $\left(\mathrm{C}_{40} \mathrm{H}_{56}\right)$ and astaxanthin $\left(\mathrm{C}_{40} \mathrm{H}_{52} \mathrm{O}_{54}\right)$ were detected in the surface of Plow (Fig. 3). $\beta$-carotene was identified by its three main Raman bands located at $1521\left(v_{1} \mathrm{C}=\mathrm{C}\right)$, $1154\left(v_{2} \mathrm{C}-\mathrm{C}\right)$, and $1001\left(v_{3} \mathrm{C}-\mathrm{H}\right) \mathrm{cm}^{-1}$ and by its overtones at $2314 \mathrm{~cm}^{-1}\left(2 v_{2}\right)$ and combination-tones at $2516 \mathrm{~cm}^{-1}\left(v_{1} v_{3}\right)$ and $2673 \mathrm{~cm}^{-1}\left(v_{1} v_{2}\right)$ ) (Fig. 3a) (Edwards et al., 1997). Astaxanthin was identified through its three main Raman bands located at $1512\left(v_{1}\right.$ $\mathrm{C}=\mathrm{C}), 1156\left(v_{2} \mathrm{C}-\mathrm{C}\right)$, and $1006\left(v_{3} \mathrm{C}-\mathrm{H}\right) \mathrm{cm}^{-1}$ (Fig. 3b) (Rivera and Pena-Diaz, 2012).

The presence of astaxanthin is of special interest due to the fact that it is the most oxidized species and it has been proposed as bio-indicator of high $\mathrm{SO}_{2}$ concentration in the atmosphere. 


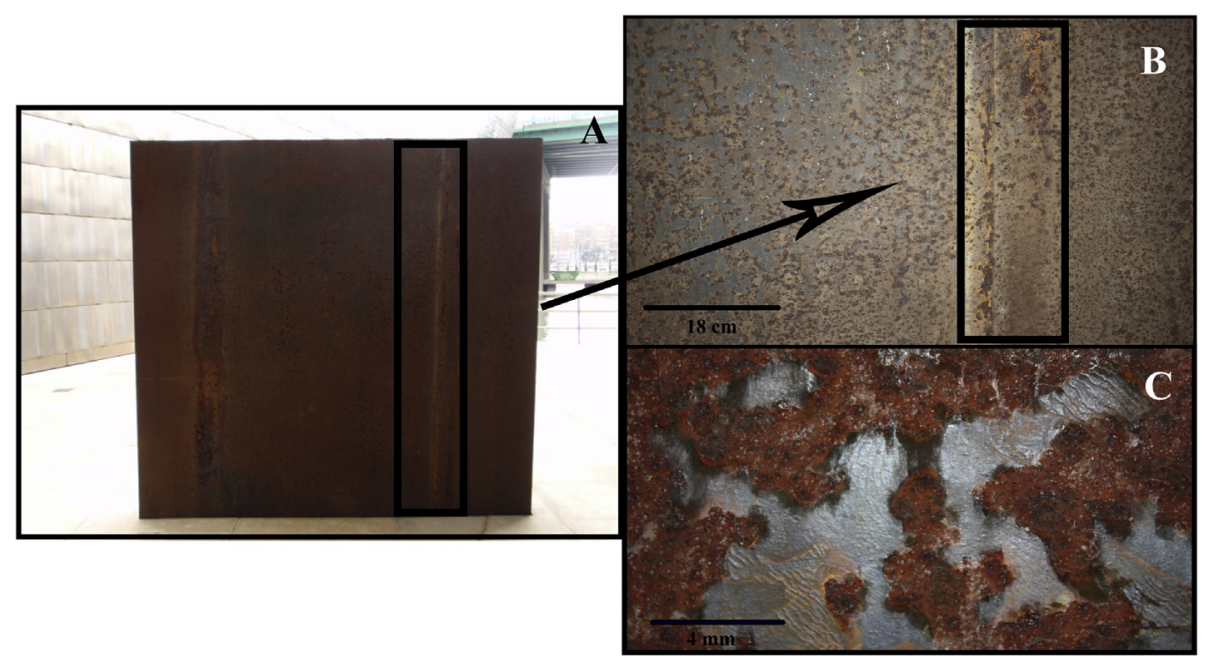

Fig. 1. A) Plow sculpture photograph. B) Detail of the steel part in contact with the wooden pallet. C) Detachment process detail.

Astaxanthin is produced by microorganisms as a self-protective mechanism, which is based on the synthesis or transformation (oxidation) of certain carotenoids to protect themselves from the oxidative damage of air pollution. This compound detected on the
Plow sample could be related to the high concentration of $\mathrm{SO}_{2}$ in Bilbao atmosphere. In previous works carried out using a $785 \mathrm{~nm}$ laser (Aramendia et al., 2012, 2013, 2014a), no signal from biological markers was detected. For some organics, especially the

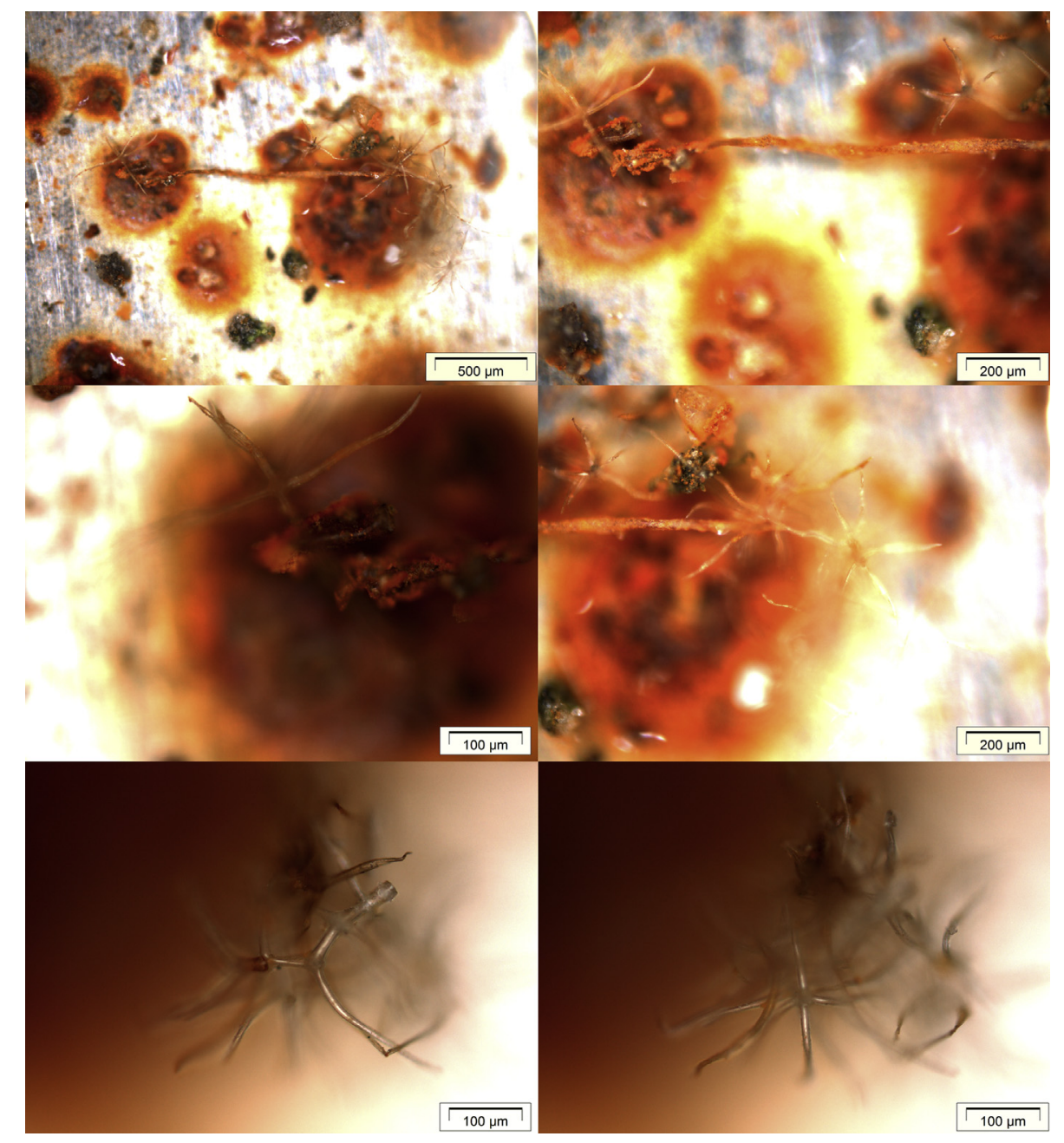

Fig. 2. Microscopic images of biological structures present on the steel surface. 


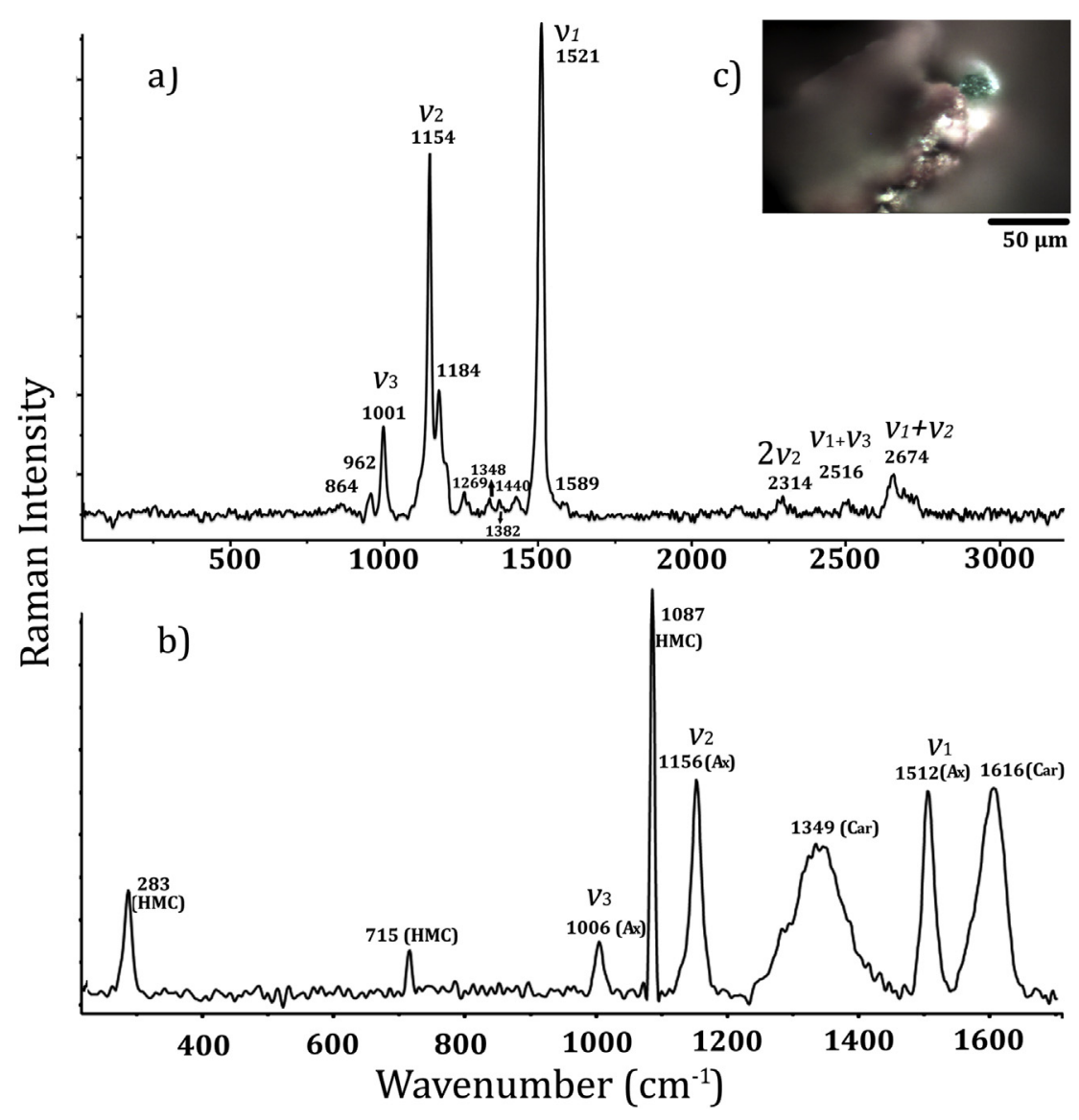

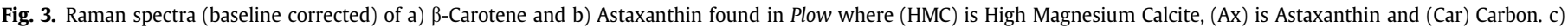
Microscopic photograph of a carotenoid in Plow steel surface.

ones with long carbon unsaturated chains, the use of a green excitation often induces some resonance effects which enhance the Raman scattering allowing its detection even with some fluorescence or low amounts of compounds. The selection of the correct excitation wavelength (514 $\mathrm{nm}$ in this case) increases significantly the detection limit for compounds associated with biological activity since it increases their Raman signal. These molecules were not detected with the $785 \mathrm{~nm}$ laser. Raman scattering intensity is proportional to $\lambda^{-4}$ where $\lambda$ is the laser wavelength. Moreover than getting out of resonance conditions, an infra-red laser thus results in a decrease in scattering intensity by a factor of 15 or more, when compared with blue/green visible lasers.

At the same time, Raman results revealed that Plow was seriously affected by biological activity. One of the main metabolites detected on the steel surface was oxalate (Fig. 4). These oxalates had different composition depending on the substrate where the microorganisms were settled. On the one hand, two different calcium oxalates were identified; mainly whewellite $\left(\mathrm{CaC}_{2} \mathrm{O}_{4} \cdot \mathrm{H}_{2} \mathrm{O}\right)$ and sporadically weddellite $\left(\mathrm{CaC}_{2} \mathrm{O}_{4} \cdot 2 \mathrm{H}_{2} \mathrm{O}\right)$ (Fig. 4) (Edwards et al., 1997; Frost and Weier, 2003).

In addition to calcium oxalates, the iron oxalate humboldtine $\left(\mathrm{Fe}\left(\mathrm{C}_{2} \mathrm{O}_{4}\right) \cdot 2 \mathrm{H}_{2} \mathrm{O}\right)$ was identified by Raman spectroscopy (Fig. 5) (Edwards et al., 1997).

Oxalates were detected only in the samples collected from those areas that had been in contact with the wooden pallet. In contrast, only in those places which were not in contact with the wood, calcite particles were detected. This could mean that in the locations with wood contact, almost all calcite reacted with the oxalic acid excreted by microorganisms to form different oxalates.

Oxalates are subproducts of the metabolism of microorganisms that are on the steel surface. Actually, in a lichen biodeterioration study calcium oxalate has been reported as the major metabolite (Edwards et al., 1997). It is well known that the calcium oxalates are formed by reaction of calcite and the oxalic acid excreted by the microorganisms (Reactions 1 and 2) (Edwards et al., 1997; Maguregui et al., 2012). In this case, calcite is provided by exogeneous particle deposition on the steel surface and it was also detected in the steel surface by Raman spectroscopy through its main Raman band at $1085 \mathrm{~cm}^{-1}$. Calcium oxalate dihydrate is metastable at ambient temperatures and its formation is favored under acidic conditions, but it can change to the monohydrate form (Edwards et al., 1997). Therefore, the main problem of the presence of these biological metabolites is based on the physical stress that they could generate on the steel surface. Depending on the humidity conditions whewellite or weddellite could be formed. In addition, with humidity changes in the atmosphere, these compounds could be transforming one into another. As occurs with the different calcium sulphate hydration forms (Irazola et al., 2011), the volume difference between both hydration forms of calcium oxalate (Molecular weight of whewellite: $146.11 \mathrm{~g} / \mathrm{mol}$ and $164.13 \mathrm{~g} /$ mol for weddellite) can generate stress on the structure favoring the detachments of steel chips in some areas of the surface.

$\mathrm{H}_{2} \mathrm{C}_{2} \mathrm{O}_{4}+\mathrm{CaCO}_{3} \rightarrow \mathrm{CaC}_{2} \mathrm{O}_{4} \cdot \mathrm{H}_{2} \mathrm{O}+\mathrm{CO}_{2}$

$\mathrm{H}_{2} \mathrm{C}_{2} \mathrm{O}_{4}+\mathrm{CaCO}_{3}+\mathrm{H}_{2} \mathrm{O} \rightarrow \mathrm{CaC}_{2} \mathrm{O}_{4} \cdot 2 \mathrm{H}_{2} \mathrm{O}+\mathrm{CO}_{2}$ 


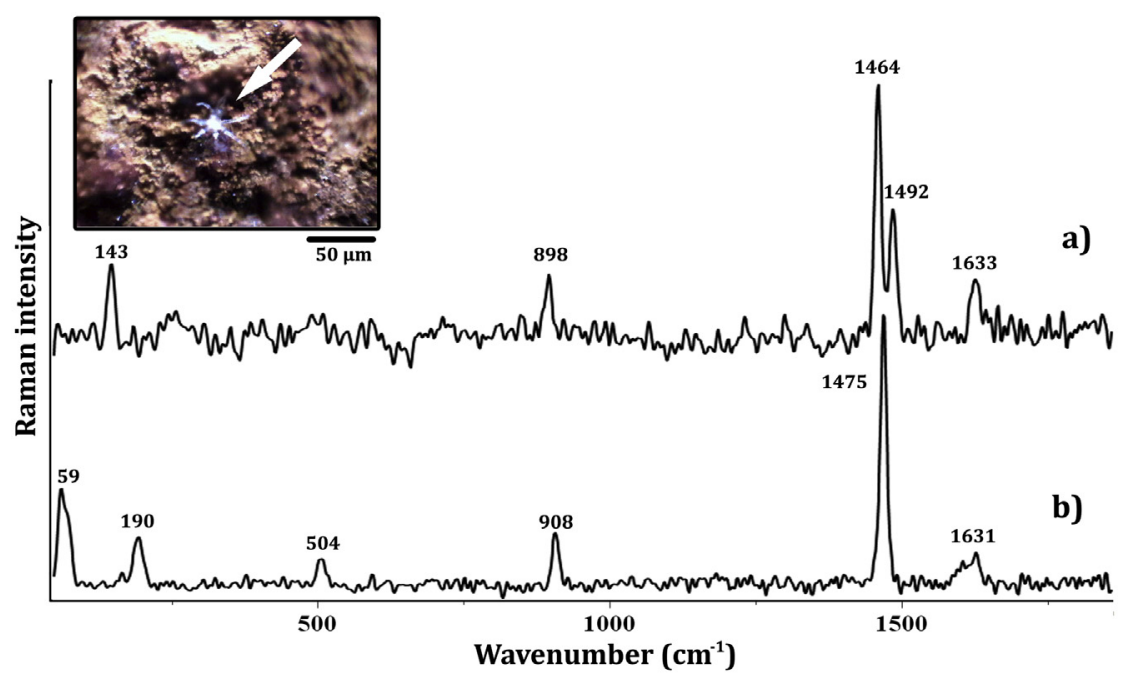

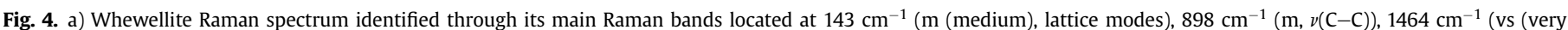

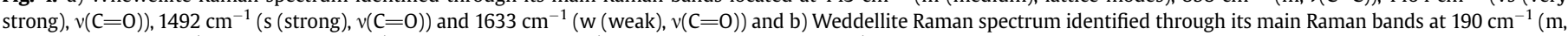

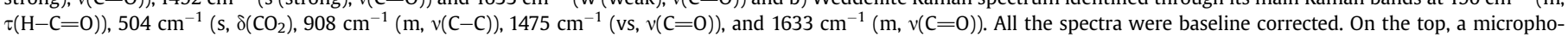
tograph of the analyzed area where a microorganism can be observed.

However, the formation mechanism of humboldtine has not been reported in the literature for steel surfaces, therefore, a thermodynamic modeling was carried out using the MEDUSA (Make Equilibrium Diagrams Using Sophisticated Algorithms) software (Puigdomenech, 2004) to elucidate the reactions occurring on the weathering steel surface. $\mathrm{SO}_{2}$ was considered in the thermodynamic simulation because of its important role in the development of the weathering steel corrosion layer (Aramendia et al., 2013). In Bilbao city, $\mathrm{SO}_{2}$ is one of the main pollutants present in the atmosphere. According to literature (De la Fuente et al., 2011 ) there is a deposition rate of $81 \mathrm{mg} \mathrm{SO} 2 \cdot \mathrm{m}^{-2}$ per day, that is, almost $300 \mathrm{~g} \mathrm{~m}^{-2}$ all along a single year. Assuming a rainy day, with a rainwater accumulation of $0.1 \mathrm{~mm}$ over the surface, there would be $0.1 \mathrm{~L}$ ( $100 \mathrm{~g}$ of water) per square meter. The solubility of $\mathrm{SO}_{2}$ is $940 \mathrm{mg}$ in $100 \mathrm{~g}$ of water. This means that the deposited $81 \mathrm{mg}$ of $\mathrm{SO}_{2}$ are completely soluble. Taking into account that Bilbao presents $3000 \mathrm{~h}$ of wetness ( 125 days), there is an accumulative effect $10 \mathrm{~g}$ of $\mathrm{SO}_{2}$ per $100 \mathrm{~g}$ of water per year or $1500 \mathrm{mM}$, only of dissolved $\mathrm{SO}_{2}$. Taking this data in main, for the thermodynamic simulation it was assumed a concentration of $200 \mathrm{mM}$, trying to resemble a reliable accumulative effect of $\mathrm{SO}_{2}$ on the surface of the steel. The Redox potential and $\mathrm{pH}$ were assumed to be $90 \mathrm{mV}$ and 6 , respectively (experimentally measured values). The simulation was carried out as a function of the oxalic acid concentration, from 0 to $40 \mathrm{mM}$.

The formation of iron oxalate depends on the presence of calcite (Fig. 6). As the concentration of calcite decreases the fraction of formed humboldtine increases (Fig. 6, from the top to the bottom). This means that calcite competes for the oxalic acid with iron. Iron oxalate would not be formed at high concentration values of calcite ( $60 \mathrm{mM}$, Fig. 6 first on the top). This thermodynamic modeling suggests that the formation of iron oxalate would take place as a direct reaction between iron (oxides) in the steel surface and microorganisms, unless calcite was present on the surface. Humboldtine is formed from any iron oxide (Fig. 6). However, in our samples magnetite $\left(\mathrm{Fe}_{3} \mathrm{O}_{4}\right)$ was the most likely iron oxalate precursor, since it is a mixed oxide of iron II and III and in the steel surface the iron (II) oxalate was found. However, due to the action

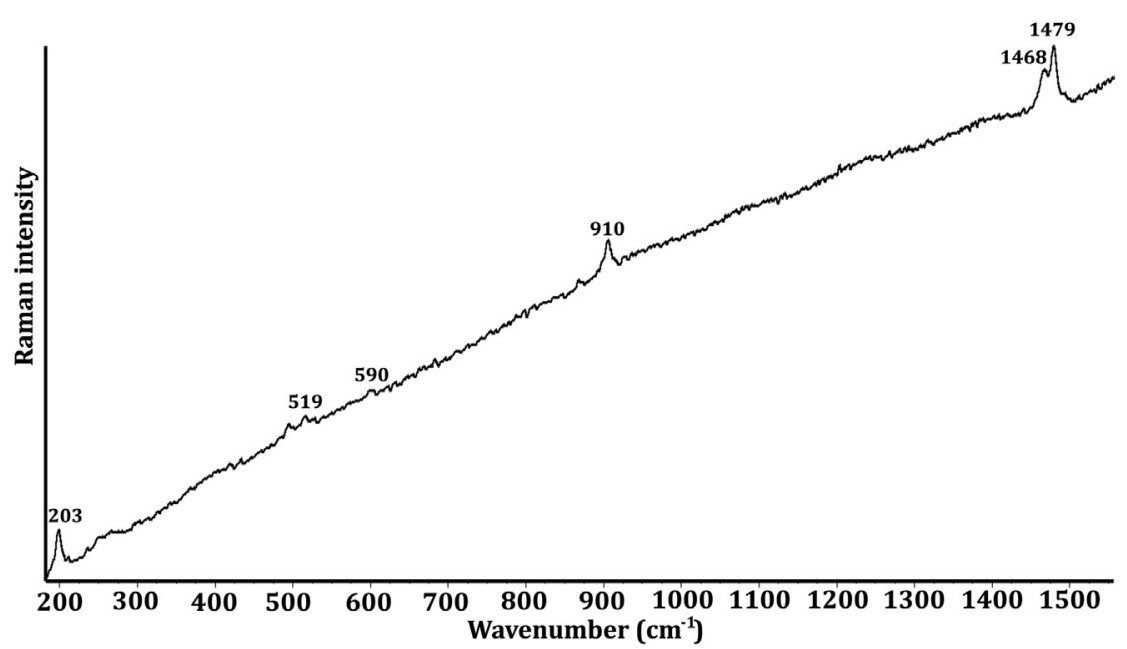

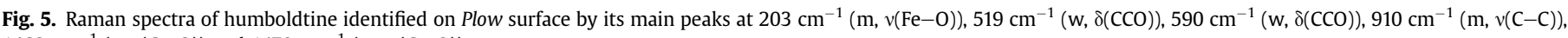
$1468 \mathrm{~cm}^{-1}(\mathrm{~s}, \mathrm{v}(\mathrm{C}=0))$ and $1479 \mathrm{~cm}^{-1}(\mathrm{vs}, \mathrm{v}(\mathrm{C}=0))$. 


\section{$\left[\mathrm{H}_{2} \mathrm{CO}_{3}\right]_{\mathrm{ToT}}=12.00 \mathrm{mM} \quad[\mathrm{Fe}(\mathrm{c})]$ тот $=10.00 \mathrm{mM}$ $\mathrm{EH}_{\mathrm{H}}=\mathbf{0 . 0 9 \mathrm { V }} \quad\left[\mathrm{SO}_{2}(\mathrm{~g})\right]_{\text {тот }}=\mathbf{2 0 0 . 0 0 \mathrm { mM }}$ $\mathrm{pH}=6$}

$\left[\mathrm{CaCO}_{3}(\mathrm{c})\right]$ тот $=\mathbf{6 0 . 0 0} \mathrm{mM}$

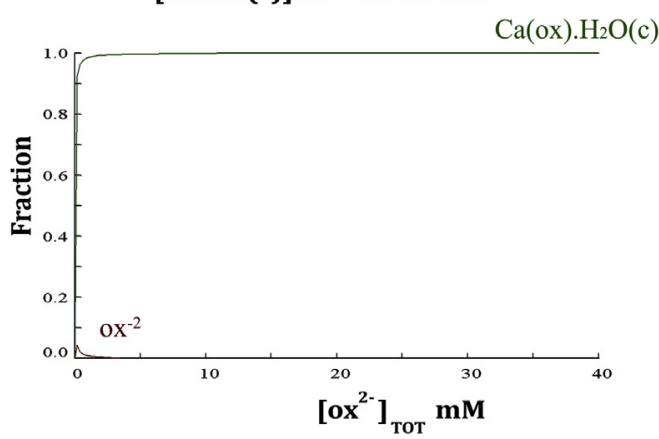

$\left[\mathrm{CaCO}_{3}(\mathrm{c})\right]$ тот $=\mathbf{3 0 . 0 0} \mathrm{mM}$

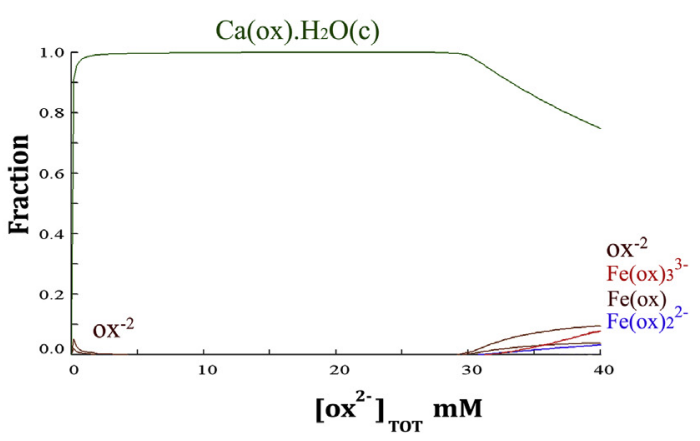

$\left[\mathrm{CaCO}_{3}(\mathrm{c})\right]$ тот $=10.00 \mathrm{mM}$

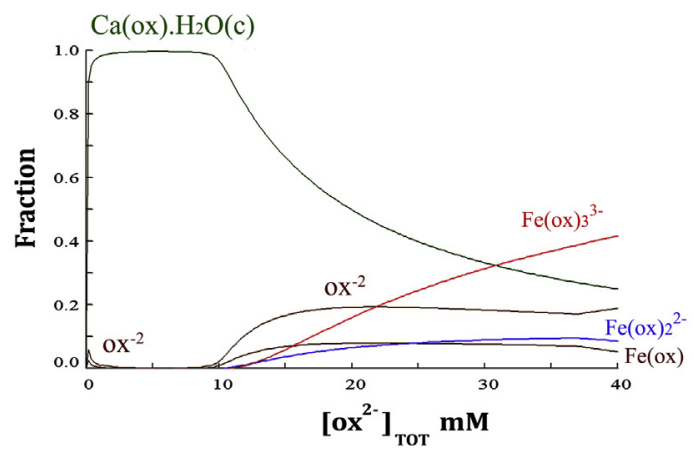

$\left[\mathrm{CaCO}_{3}(\mathrm{c})\right]$ тот $=\mathbf{0 . 0 0} \mathrm{mM}$

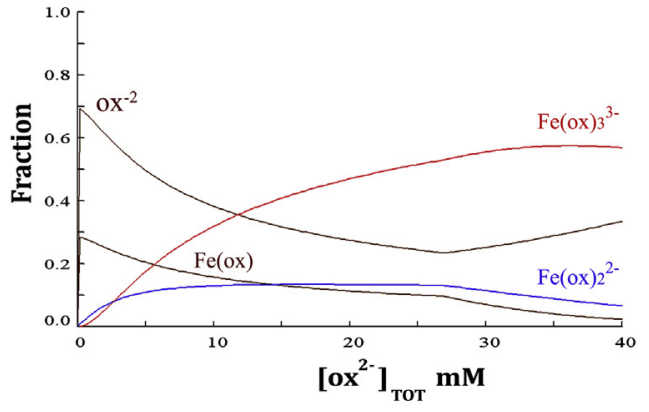

Fig. 6. MEDUSA diagrams for humboldtine formation at different concentrations of calcite. On the top the conditions used for all the diagrams. of $\mathrm{SO}_{2}$, some iron (III) phases can be reduced to iron (II) becoming also precursors for iron (II) oxalate. It is worthy to point out that in the special case of this sculpture, the surface was not sandblasted and the black patina formed during the rapid cooling of the material, which is composed by magnetite, still remained. Therefore the massive presence of magnetite could promote the formation of $\mathrm{Fe}\left(\mathrm{C}_{2} \mathrm{O}_{4}\right) \cdot 2 \mathrm{H}_{2} \mathrm{O}$ on this material. The formation reaction of humboldtine would be that shown in Reaction 3 where hematite would be generated. Apart from the this compound, other iron oxalate species can be formed in the chemical system (see Figs. 6 and $7 \mathrm{~b}$ ) like the trioxalate complex of Fe(III), following Reaction 4. However, they were not identified by Raman spectroscopy because only the neutral humboldtine is present when it precipitates (the measurements were done on solid phases). Notice that iron (II) sulphate is also formed in the system (Fig. 7b). In fact, rozenite $\left(\mathrm{FeSO}_{4} \cdot 4 \mathrm{H}_{2} \mathrm{O}\right)$ was also detected by Raman spectroscopy in the steel samples, surely coming from the precipitation of that iron sulphate (Aramendia et al., 2013).

Regarding the calcium fraction, at the oxalic concentration necessary to form humboldtine, the predominant calcium sulphate is anhydrite and calcite does not appear in the thermodynamic diagram (Fig. 7a). This fact can support the absence of calcite in the surface affected by microorganisms and the presence of anhydrite.

$$
\begin{aligned}
& \mathrm{H}_{2} \mathrm{C}_{2} \mathrm{O}_{4}+\mathrm{Fe}_{3} \mathrm{O}_{4}+\mathrm{H}_{2} \mathrm{O} \rightarrow \mathrm{FeC}_{2} \mathrm{O}_{4} \cdot 2 \mathrm{H}_{2} \mathrm{O}++\mathrm{Fe}_{2} \mathrm{O}_{3} \\
& \mathrm{Fe}^{3+}+3 \mathrm{H}_{2} \mathrm{C}_{2} \mathrm{O}_{4} \rightarrow \mathrm{Fe}\left(\mathrm{C}_{2} \mathrm{O}_{4}\right)_{3}^{-3}+6 \mathrm{H}^{+}
\end{aligned}
$$

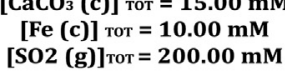

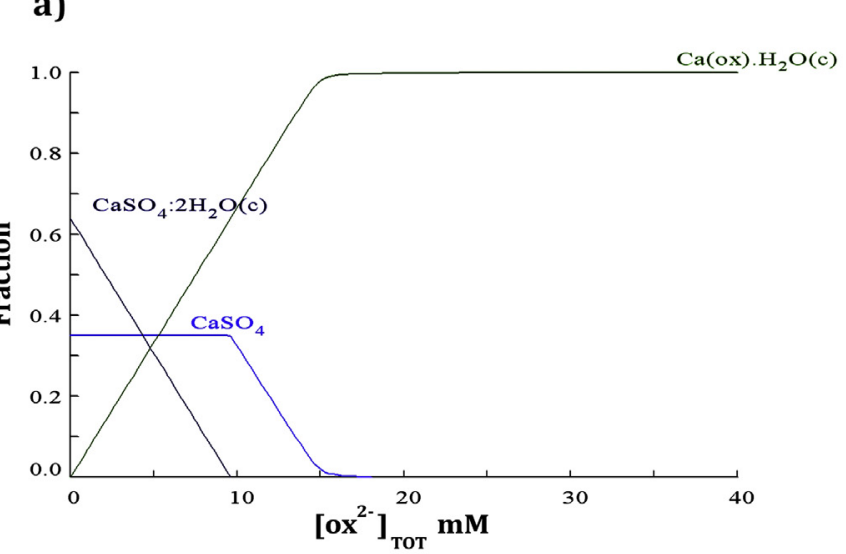

b)

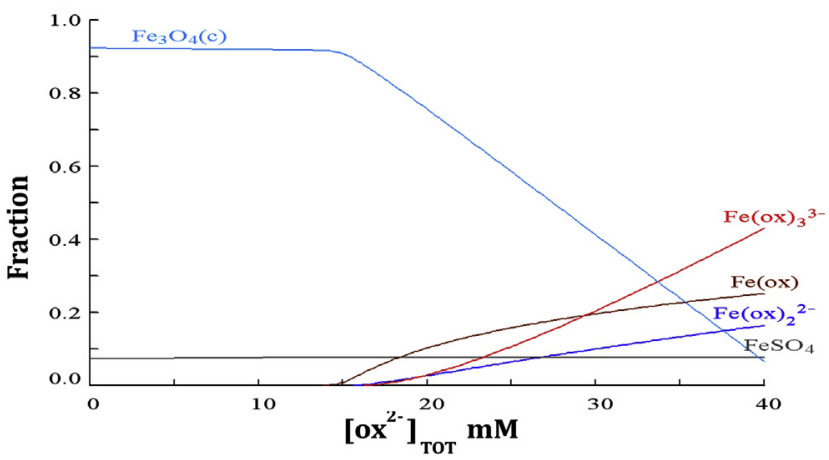

Fig. 7. a) Fraction of calcium species and b) fraction of iron species during the formation of humboldtine on weathering steel surface. The chemical condition to perform the simulations are written in the top. 
The presence of different hydration forms of calcium oxalates can generate a physical stress due to their volume difference. The transformation from one into another can be the cause of the detaching processes that the sculpture is suffering. For example, if one oxalate is located in a surface crack and this oxalate, due to changes in moisture, is transformed into another more voluminous hydration form of that oxalate, with the time and after several wet-dry cycles the crack development could form a flake of corrosion layers that can be detached from the sculpture body. The presence of humboldtine is indicative of a different form of material deterioration. The formation of this compound starts from magnetite that is a component of the protective rust layer in this material. Therefore, the consumption of this iron oxide implies iron consumption in the material. The formation of the trioxalate complex of $\mathrm{Fe}(\mathrm{III})$ has as a consequence the acidification of the surface (see Reaction 4), which would increase the deterioration of the protective rust layer and the appearance of the steel surface underneath. In the same way, the formation of that complex promotes the loss of material due to the run-off process of soluble compounds by rain water.

\section{Conclusions}

Oxalates were detected by Raman spectroscopy only in the place where the pallet was in contact with the steel that was used for the transportation of the sculpture. Therefore, the oxalate formation and the presence of wood must be linked. Its presence exerts two kinds of effects in the weathering steel. On the one hand, the physic stress induced by calcium oxalates can be the responsible for the irregularities in the protective layer produced by the detachment of steel flakes. On the other hand, iron oxalate can be exerting the color changes in the surface since humboldtine is yellowish. The presence of oxalates has not been reported in these contexts in the literature. Besides, only in the same areas where oxalates were found, that is, the areas in contact with the pallet, $\beta$-carotene and astaxanthin were found. These compounds are biomarkers for a large number of prokaryotic and eukaryotic microorganisms, suggesting biological activity on a weathering steel surface, affecting the stability and chemical integrity of the surface.

\section{Acknowledgments}

J. Aramendia and L. Gomez-Nubla are grateful to the University of the Basque Country (UPVEHU) for their post-doctoral and predoctoral grants. J. Aramendia is also grateful to the Basque Government for her Mobility Grant in MONARIS laboratory. We would like to thank Bilbao Guggenheim Museum for all the support during the analysis of the sculpture. This work has been financially supported by the Spanish Ministry of Economy and Competitiveness (MINECO) through the project DISILICA-1930 (ref. BIA2014-59124).

\section{References}

Aramendia, J., Gomez-Nubla, L., Castro, K., Martinez-Arkarazo, I., Vega, D., Sanz López de Heredia, A., García Ibáñez de Opakua, A., Madariaga, J.M., 2012 Portable Raman study on the conservation state of four CorTen steel-based sculptures by Eduardo Chillida impacted by urban atmospheres. J. Raman Spectrosc. 43, 1111-1117.

Aramendia, J., Gomez-Nubla, L., Arrizabalaga, I., Prieto-Taboada, N., Castro, K. Madariaga, J.M., 2013. Multianalytical approach to study the dissolution process of weathering steel: the role of urban pollution. Corros. Sci. 76, 154-162.

Aramendia, J., Gomez-Nubla, L., Castro, K., Madariaga, J.M., 2014a. Spectroscopic speciation and thermodynamic modeling to explain the degradation of weathering steel surfaces in $\mathrm{SO}_{2}$ rich urban atmospheres. Microchem. J. 115, $138-145$

Aramendia, J., Gomez-Nubla, L., Bellot-Gurlet, L., Castro, K., Paris, C., Colomban, P., Madariaga, J.M., 2014b. Protective ability index measurement through Raman quantification imaging to diagnose the conservation state of weathering steel structures. J. Raman Spectrosc. 45, 1076-1084.

Arroyabe, C., Morcillo, M., 1995. The effect of nitrogen oxides in atmospheric corrosion of metals. Corros. Sci. 37, 293-305.

Basheer, R., Ganga, G., Chandran, R.K., Nair, G.M., Nair, M.B., Shibli, S.M., 2013. Effect of $\mathrm{W}-\mathrm{TiO}_{2}$ composite to control microbiologically influenced corrosion on galvanized steel. Appl. Microbiol. Biotechnol. 97, 5615-5625.

Castro, K., Pérez-Alonso, M., Rodríguez-Laso, M.D., Fernández, L.A., Madariaga, J.M., 2005. On-line FT-Raman and dispersive Raman spectra database of artists' materials (e-VISART database). Anal. Bioanal. Chem. 382, 248-258.

Castro, K., Sarmiento, A., Martinez-Arkarazo, I., Madariaga, J.M., Fernandez, L.A., 2008. Green Copper pigments biodegradation in cultural heritage: from Malachite to Moolooite, thermodynamic modeling, X-ray fluorescence, and Raman evidence. Anal. Chem. 80, 4103-4110.

Chertov, O., Gorbushina, A., Deventer, B., 2004. A model for microcolonial fungi growth on rock surfaces. Ecol. Model. 177, 415-426.

Chiavari, C., Bernardi, E., Martini, C., Passarini, F., Motori, A., Bignozzi, M.C., 2012. Atmospheric corrosion of Cor-Ten steel with different surface finish: accelerated ageing and metal release. Mater. Chem. Phys. 136, 477-486.

De la Fuente, D., Díaz, I., Simancas, J., Chico, B., Morcillo, M., 2011. Long-term atmospheric corrosion of mild steel. Corros. Sci. 53, 604-617.

Diefallah, El.-H.M., Mousa, M.A., El-Bellihi, A.A., El-Mossalamy, E.-H., El-Sayed, G.A., Gabal, M.A., 2002. Thermal decomposition of iron(II) oxalate-magnesium oxalate mixtures. J. Anal. Appl. Pyrolysis 62, 205-214.

Dornieden, Th, Gorbushina, A.A., Krumbein, W.E., 2000. Biodecay of cultural heritage as a space/time-related ecological situation an evaluation of a series of studies. Int. Biodeteorirat. Biodegrad. 46, 261-270.

Downs, R.T., 2006. Program and Abstracts of the 19th General Meeting of the International Mineralogical Association in Kobe, Japan. 003, 13. http://rruff.info.

Edwards, H.G.M., Russel, N.C. Seaward, M.R.D., 1997. Calcium oxalate in lichen biodeterioration studied using FT-Raman spectroscopy. Spectrochim. Acta A 53, 99-105.

Frost, R.L., Weier, M.L., 2003. Raman spectroscopy of natural oxalates at 298 and 77 K. J. Raman Spectrosc. 34, 776-785.

Gaylarde, C.C., Morton, L.H.G., Loh, K., Shirakawa, M.A., 2011. Biodeterioration of external architectural paint films - a review. Int. Biodeterior. Biodegrad. 65, 1189-1198.

Hernanz, A., Gavira-Vallejo, J.M., Ruiz-Lopez, J.F., Edwards, H.G.M., 2008. A comprehensive micro-Raman spectroscopic study of prehistoric rock paintings from the Sierra de las Cuerdas, Cuenca, Spain. J. Raman Spectrosc. 39, 972-984.

Irazola, M., Olivares, M., Castro, K., Maguregui, M., Martinez-Arkarazo, I., Madariaga, J.M., 2011. In situ Raman spectroscopy analysis combined with Raman and SEM-EDS imaging to assess the conservation state of 16th century wall paintings. J. Raman Spectrosc. 43, 1676-1684.

Javaherdashti, R., Singh Raman, R.K., Panter, C., Pereloma, E.V., 2006. Microbiologically assisted stress corrosion cracking of carbon steel in mixed and pure cultures of sulfate reducing bacteria. Int. Biodeterior. Biodegrad. 58, 27-35.

Kamimura, T., Hara, S., Miyuki, H., Yamashita, M., Uchida, H., 2006. Composition and protective ability of rust layer formed on weathering steel exposed to various environments. Corros. Sci. 48, 2799-2812.

Kozirog, A., Otlewska, A., Piotrowska, M., Rajkowska, K., Nowicka-Krawczyk, P., Hachulka, M., Wolski, G.J., Gutarowska, B., Kunicka-Styczyńska, A., Libudzisz, Z., Zakowska, Z., Żydzik-Białek, A., 2014. Colonising organisms as a biodegradation factor affecting historical wood materials at the former concentration camp of Auschwitz II - Birkenau. Int. Biodeterior. Biodegrad. 86, $171-178$.

Laiz, L., May 2015. Aplicaciones prácticas de la investigación sobre Patrimonio. http://digital.csic.es/bitstream/10261/64927/1/Aplicaciones\%20pr\%c3\%A1cticas \%20de\%20la\%20investigaci\%C3\%B3n\%20sobre\%20patrimonio.pdf. last visit.

Maguregui, M., Knuutinen, U., Trebolazabala, J., Morillas, H., Castro, K., MartinezArkarazo, I., Madariaga, J.M., 2012. Use of in situ and confocal Raman spectroscopy to study the nature and distribution of carotenoids in brown patinas from a deteriorated wall painting in Marcus Lucretius House (Pompeii). Anal. Bioanal. Chem. 402, 1529-1539.

Mandrioili, P., Caneva, G., Sabbioni, C. (Eds.), 2003. Cultural Heritage and Aerobiology: Methods and Measurement Techniques for Biodeterioration Monitoring. Springer, Netherlands.

Miranda, E., Bethencourt, M., Botana, FJ. Cano, M.J. Sanchez-Amaya, J.M., Corzo, A. Garcia de Lomas, J., Fardeau, M.L., Ollivier, B., 2006. Biocorrosion of carbon steel alloys by an hydrogenotrophic sulfate-reducing bacterium Desulfovibrio capillatus isolated from a Mexican oil field separator Corros. Sci. 48, 2417-2431.

Oesch, $\mathrm{S} ., 1996$. The effect of $\mathrm{SO}_{2}, \mathrm{NO}_{2}, \mathrm{NO}$ and $\mathrm{O}_{3}$ on the corrosion of carbon steel and weathering steel- the results of laboratory exposures. Corros. Sci. 38, 1357-1368.

Perez-Rodriguez, J.L., Duran, A., Centeno, M.A., Martinez-Blanes, J.M., Robador, M.D., 2011. Thermal analysis of monument patina containing hydrated calcium oxalates. Termochim. Acta 512, 5-12.

Prinsloo, L.C., Barnard, W., Meiklejohn, I., Hall, K., 2008. The first Raman spectroscopic study of San rock art in the Ukhahlamba Drakensberg Park, South Africa. J. Raman Spectrosc. 39, 646-654.

MEDUSA (Make Diagrams Using Sophisticated Algorithms), version 15 Puigdomenech, I., 2004. Department of Inorganic Chemistry, the Royal Institute of Technology. Sweden, Stockholm. http://www.kth.se/che/medusa (last accessed May 2015). 
Rémazeilles, C., Saheb, M., Neff, D., Guilminot, E., Tran, K., Bourdoiseau, J.A., Sabot, R., Jeannin, M., Matthiesen, H., Dillmann, P., Refait, P., 2010. Microbiologically influenced corrosion of archaeological artefacts: characterization of iron(II) sulfides by Raman spectroscopy. J. Raman Spectrosc. 41, 1425-1433.

Rivera, S.M., Pena-Diaz, A.L., 2012. Brick and Mortar Research. Nova (New York).

Rosado, T., Gil, M., Mirao, J., Candeias, A., Caldeira, A.T., 2013. Oxalate biofilm formation in mural paintings due to microorganisms, A comprehensive study. Int. Biodeterior. Biodegrad. 85, 1-7.

St Clair, L.L., Seaward, M.R.D. (Eds.), 2004. Biodeterioration of Stone Surfaces. Springer, Netherlands.
Sterflinger, K., 2010. Fungi: their role in deterioration of cultural heritage. Fungal Biol. Rev. 24, 47-55.

Tournié, A., Prinsloo, L.C., Paris, C., Colomban, Ph, Smith, B.W., 2011. The first in situ Raman spectroscopic study of San rock art in South Africa: procedures and preliminary results. J. Raman Spectrosc. 42, 399-402.

Wang, J.H., Wei, F.I., Chang, Y.S., Shih, H.C., 1997. The corrosion mechanisms of carbon steel and weathering steel in $\mathrm{SO}_{2}$ polluted atmospheres. Mater. Chem. Phys. 47, 1-8.

Yuan, S.J., Pehkonen, S.O., 2007. Microbiologically influenced corrosion of 304 stainless steel by aerobic Pseudomonas NCIMB 2021 bacteria: AFM and XPS study. Colloids Surf. B 59, 87-99. 